\title{
Corporate Law Reform and the Political Environment: An Empirical Analysis Employing Public-Comment Procedure Data in Japan
}

\author{
Hatsuru MORITA* \\ School of Law, Tohoku University, Miyagi
}

\begin{abstract}
Corporate law shapes the fundamental business environment and affects various stakeholders. It is possible to determine the behaviour of various stakeholders by examining the politics of the reform process of corporate law. In order to understand the process, this paper uses the notice-and-comment procedure (public-comment procedure). Under this procedure, people submit comments to the Ministry of Justice; some of the comments are reflected in the final Bill, while others are not. The paper performs a quantitative analysis of a hand-collected dataset from two recent public-comment procedures on corporate law reform. The results showed that the bureaucrats are rigid and not willing to take public comments seriously. However, on some technical issues, legal academics, and legal professionals influence the behaviour of the bureaucrats. In addition, the bureaucrats employed these comments to honour the technical views of professionals. In other cases, corporate managers significantly influence the reform process.
\end{abstract}

Keywords: corporate law, political process, empirical analysis, public comment, bureaucracy

\section{INTRODUCTION ${ }^{1}$}

Corporate law shapes the fundamental business environment and, therefore, influences various stakeholders, such as shareholders, managers, employees, stock markets, securities brokers, and creditors. Each stakeholder has the incentive to exercise its influence over the

* Correspondence to Professor Hatsuru Morita, School of Law, Tohoku University, 27-1 Kawauchi Aoba, Sendai, Miyagi 980-8576, Japan. E-mail address: hatsuru@law.tohoku.ac.jp. The earlier version of this paper has benefitted from many helpful comments by Gen Goto, Izuru Makihara, Yukichi Mano, Tomoyo Matsui, Hiroaki Matsuura, Kazuyuki Sato, Mamoru Sorai, and seminar participants at the Economic Analysis of Law Workshop, Tohoku University, Goethe-Universität Frankfurt am Main, and Max-Planck-Institut für ausländisches und internationales Privatrecht, and anonymous referees. The research is supported by a grant-in-aid from Zengin Foundation for Studies on Economics, Tohoku University, and JSPS grant-in-aid 16H03564.

1. Part of this paper is a revised version of my paper in Japanese (Morita, 2005). The revisions from Morita (2005) are twofold. The first revision is an empirical (or statistical) one. Morita (2005) did not account for heterogeneity of the influences from various stakeholders. This paper tries to account for this heterogeneity by introducing interaction terms between various stakeholders and type of issues (see Morita (2014a), pp. 160-1). In addition, multinomial-probit/logit analyses in Morita (2005) are redundant. Thus, this paper drops multinomial analyses from Morita (2005) and tries to make the presentation more comprehensible. The second revision is a theoretical (or descriptive) one. After Morita (2005), the Ministry of Justice of Japan stopped publishing individual results of public comments and it is no longer possible to implement another empirical analysis of the public-comment procedure in the same way. However, we have experienced several reforms of Japanese corporate law since 2005 and we could check whether the theoretical inferences acquired from the 2005 Japanese paper are applicable to these reforms. In addition, it is helpful to put the analysis into 
formation process of corporate law. For example, corporate managers may want to build robust entrenchment measures against attacks from shareholders and hostile acquirers; minority shareholders may want to install safety nets in order to guard themselves against the mismanagement of majority shareholders; and stock exchanges may want to maximize their market-fee revenue, and so on.

Because the business environment and the demand for corporate law have been changing continuously and rapidly, many countries have reformed their corporate laws frequently. In addition, various corporate stakeholders have influenced the process of these reforms. Japan is no exception. This paper attempts to shed light on how various stakeholders behave in the process of corporate law reform. By understanding the political environment of this process, we can acquire a better understanding of corporate law and the necessary steps to improve it.

There is a rich literature on the political aspect of corporate law. In an early effort Roe, discussed the political formation of corporate governance in the US. ${ }^{2}$ With respect to Japanese corporate law, ${ }^{3}$ West is a more recent contribution to the literature. ${ }^{4}$ This paper tries to add another dimension on the political environment of corporate law.

Previous studies focused on the various stakeholders surrounding corporate law, such as corporate managers, shareholders, and creditors. However, these stakeholders cannot form corporate law by themselves. Instead, legislatures and judges perform this role. These lawmakers have their own incentives and do not necessarily follow the instructions from the stakeholders. Therefore, we need to understand the political incentives of both law-makers and corporate stakeholders. This paper focuses on the influence of stakeholders on the behaviour of bureaucrats of the Ministry of Justice (MOJ).

This paper also refers to the rich literature on bureaucracy in general and Japanese bureaucracy in particular. Previous studies focused on the Ministry of Finance (MOF) and Ministry of Economy, Trade, and Industry (METI), both of which are powerful policy planners. ${ }^{5}$ However, no research so far has focused on the bureaucrats of the MOJ. This is surprising given the important role played by the MOJ in the general law-making process in areas such as the Civil Code, Commercial Code, Criminal Code, Civil Procedure Code, Criminal Procedure Code, and Corporate Code. This paper is the first attempt to focus on the bureaucrats of the MOJ.

To this end, the paper performs a quantitative analysis on a dataset collected from two recent public-comment procedures on corporate law reform. Fortunately, in two recent corporate law reforms, the 2002 reform and the 2005 reform, comments solicited through public-comment procedures are available. Employing these data, we estimated which comments the MOJ bureaucrats took seriously. Thus, we can understand the mechanism of the corporate law reform process, especially regarding the relative political power of various interest groups.

(F'note continued)

the historical context of the political aspect of Japanese corporate law. Therefore, this paper adds an analysis on the connection between the empirical part and the political environment. This part is borrowed from Morita (2014b).

2. Roe (1996).

3. For an overview of corporate law reforms in Japan, see e.g. Milhaupt (2003).

4. West (2001).

5. One of the most famous examples is Kato (1994), which analyzed the tax authority in Japan. 
The results of the quantitative analysis showed that the bureaucrats in general were rigid and unwilling to take public comments seriously. However, the extent of this tendency depended on the nature of the proposal put forward in the public-comment procedure. For example, regarding some technical issues, legal academics and legal professionals, such as courts and law firms, were able to influence the behaviour of the bureaucrats. The bureaucrats employed these comments to counterbalance politically powerful interest groups and to honour the technical views of legal professionals.

In other cases, the results showed that corporate managers significantly influenced the reform process. When an issue was a technical one and not fully discussed in the Legislative Council, corporate managers employed the public-comment procedure as another vehicle for achieving their intentions. This seemingly weak influence of politically powerful corporate managers could be explained by the fact that corporate managers do not need to realize their goals through the public-comment procedure because they can use another political process. ${ }^{6}$

The rest of the paper is organized as follows. Section 2 provides a brief overview of the legislative history of Japanese corporate law. Section 3 discusses the role of the publiccomment procedure and several possible hypotheses on the role of stakeholders. Section 4 describes the data and the empirical strategy. Section 5 discusses the results of the empirical analysis. Finally, Section 6 provides several concluding remarks.

\section{BACKGROUND: THE LEGISLATIVE PROCESS OF JAPANESE CORPORATE LAW}

This section provides a brief overview of the regulatory environment of the law-making process in Japan. In order to understand the power of the relevant stakeholders, we need to understand the basic structure of the law-making process in Japan. Because the law-making process differs among the different areas of law, this section focuses on the process of corporate law.

\subsection{The Old Legislative Process}

Japanese corporate law has experienced repeated reforms. It was first proposed in 1890 as a part of the Commercial Code, which was drafted under the influence of the German scholar, Herman Roesler. However, like the Civil Code, the Commercial Code of 1890 was not enforced, and a new code was enacted in 1899. The Commercial Code of 1899 was subsequently reformed in 1911 and 1938.

After World War II, Japanese law was subject to the influence of US law, and corporate law was no exception. Japanese corporate law was reformed in 1948 and 1950 in order to incorporate the US-style corporate law system. After this change, Japanese corporate law had been relatively stable for a while. However, during the period of high economic growth, Japanese corporate law was modified in response to repeated corporate scandals. It experienced a drastic change in 1974, and subsequent reforms were implemented in 1981, 1990, 1993, and 1994. The main purpose of these reforms was to strengthen the monitoring system of management in response to corporate scandals. ${ }^{7}$

6. A detailed analysis of this mechanism is found in Morita, 2014b, supra note 1.

7. Part of the background of these reforms is analyzed in Caplan (2007). 
These reforms were implemented under the old legislative process. The process applies to private laws as well as corporate law. The process is as follows:

1. The MOJ consults the Legislative Council (Housei Shingikai) to make reform reports.

2. The Legislative Council discusses the issue and makes reports by unanimous consent. ${ }^{8}$

3. The MOJ drafts a reform proposal Bill.

4. The Cabinet Legislation Bureau (CLB) checks its consistency with the Constitution and precedence.

5. CLB, MOJ, and Legislative Council members discuss the Bill.

6. The Cabinet approves the Bill and tables it in the Diet.

7. During the Diet deliberation, modifications to the original Bill rarely occur.

Under this old legislative process, changes to Bills during the Diet deliberations are relatively rare events, and the most important decision-making body is the Legislative Council. Therefore, the structure of the council is of great importance to the legislative process.

The members of the council consist of legal academics, attorneys, judges, stock market participants (e.g. security brokers and stock exchanges), and representatives of the managers of major corporations. In addition, the members of the secretariat of the council, who are legal experts (usually transferred from judges and prosecutors), play an important role; they not only manage the council meetings, but also prepare agendas for each meeting and engage in consensus building among the council members before each meeting. Because the decision of the council requires unanimous consent in practice, the manoeuvre of the secretariat is of critical importance. The members of the secretariat are judges and government officials of the MOJ, MOF, and METI.

It is characteristic of the old legislative process that only corporate managers are directly represented in the council among the various stakeholders of corporations. Neither employees, who are usually represented by labour unions, nor corporate creditors have representatives in the council. Labour unions are not represented in the council, probably because Japanese labour unions do not consider corporate law as a means of protecting corporate employees. In addition, except banks, general corporate creditors do not have a political foundation and hence cannot be represented in the council.

The strong presence of corporate managers and the absence of employees and creditors could have engendered political imbalance in shaping Japanese corporate law. However, conventionally, legal academics in the council have protected the interests of shareholders, employees, and creditors, thereby counterbalancing the political power of corporate managers and achieving an equitable compromise among the various stakeholders in corporate law.

If the council had been managed democratically, the corporate managers, who have strong political power, could have guided Japanese corporate law according to their own interests. However, under the old legislative process, the overrepresentation of legal academics

8. Formally, the Legislative Council employs majority rule (plurality rule) as its decision-making rule (Art. 7 of Housei Shingikai Rei (http://law.e-gov.go.jp/htmldata/S24/S24SE134.html, accessed 27 June 2017)). However, conventionally, almost all of its decisions are made by unanimous consent. 
has played a critical role. Thus, the undemocratic nature of the council has enabled the well-balanced development of Japanese corporate law. ${ }^{9}$

\subsection{The Turning Point: The 1997 Reform of Corporate Law}

However, the legislative environment changed drastically at the end of the twentieth century. As noted above, the Japanese economy had enjoyed high growth until 1990. Under this economic boom, severe conflicts of interest among corporate stakeholders had not been materialized. However, at the beginning of the 1990s, the bubble economy collapsed, and the Japanese economy slid into a deep depression. The Nikkei Stock Average hit a height of 38,957 yen on 29 December 1989, but it fell to below 10,000 yen over the next two decades.

This economic downturn led to an intensive search for the means to revive the Japanese economy and to increase stock prices on the Tokyo Stock Exchange. At that time, the idea that "good" corporate law, which enables "good" corporate governance, brings a strong national economy had gained popularity. This double motivation increased the pressure to reform corporate law as promptly and flexibly as possible.

However, the old legislative process was considered inappropriate for such flexible and speedy corporate law reform. Under the old legislative process, reform Bills were required to go through deliberation in the Legislative Council, which takes a long time and a huge effort. The criticism against the old legislative process was that the Legislative Council was too cautious and slow to improve corporate governance in Japan and the Japanese economy.

Under such an environment, Keidanren, the most powerful interest group of corporate managers, and some members of the ruling Liberal Democratic Party (LDP) cooperated to implement a breakthrough in the old legislative process: the 1997 reform. Under the old legislative process, a reform Bill had to go through the Legislative Council and then be tabled in the Diet by a member of the Cabinet. However, the 1997 reform Bill was tabled by members of the Diet, not by a member of the Cabinet. The 1997 Bill did not go through the Legislative Council either. The Diet members who submitted the Bill to the Diet argued that this process was more democratic than the old legislative process, because the Legislative Council and the MOJ had only a weak democratic foundation.

The main drivers of the 1997 reform were corporate managers, who formed the strong interest group, Keidanren. They were frustrated by the compromising characteristics of the old legislative process. They had been forced to make compromises with legal academics and were not able to implement the corporate law reforms that they wanted. By bypassing the Legislative Council and employing the Diet members' Bill system, they were able to realize their interests more directly. Interestingly, the mitigating role of legal academics was not included in the process of the 1997 reform.

\subsection{The New Legislative Process: The Aftermath of the 1997 Reform}

Although the 1997 reform was criticized on the grounds that the reform Bill was drafted behind closed doors, and the Diet members' Bill system was rarely employed afterwards, it fundamentally changed the political environment. The recognition of the existence of the

9. Of course, whether the nature of the Legislative Council is democratic or undemocratic depends on the definition of "democracy." Here we define "democracy" as a formal representative system that reflects a result of an election directly where a political power of strong interest parties is not weakened, not a substantive representative system. 
Diet members' Bill system, through which corporate managers can avoid the influence of legal academics and other constituencies, changed the political picture of corporate law reform.

Even if the Legislative Council is still in place, legal academics and other corporate stakeholders can no longer use it to carry through their claims. Corporate managers have more influence than before because they can employ the Diet members' Bill system as the last resort, in which their interests are considered preferentially. In other words, the outside option of corporate managers has changed drastically, and the political structure of corporate law reform has changed.

Under the new structure, every deliberation in the Legislative Council is carried on in the shadow of the Diet members' Bill system. This effect has strengthened the bargaining power of corporate managers. In addition, the deliberation time in the Legislative Council has been reduced. The long deliberation time was one of the alleged disadvantages of the old legislative process, and the strong bargaining power of corporate managers has enabled the accurate prediction of compromise among the council members. Consequently, many corporate law reforms have been implemented in Japan during the last decade.

The key feature of the new legislative process is the recognition of the Diet members' Bill system, in which the interests of corporate managers take priority, because the LDP has been accepting large political contributions from business groups and has prioritized their interests. However, after 2009, this political environment changed and became relatively unstable.

In 2009, the LDP lost the general election for the Lower House and the Democratic Party of Japan (DPJ) took office. Because the labour unions are strong supporters of the DPJ, this government began to prepare an employee-oriented corporate law reform. ${ }^{10}$ However, the DPJ lost both the 2010 Upper House election and the 2012 Lower House general election. The DPJ left office, and the LDP regained control of the government. The political environment surrounding Japanese corporate law has become unstable.

\subsection{Evaluating the Change}

Under the old legislative process, the undemocratic feature of the Legislative Council has led to the overrepresentation of stakeholders who cannot convey their interests through the standard democratic process. This feature enabled a fair balance among various corporate law stakeholders.

In contrast, the new legislative process is more democratic than the other one was. Under today's political system, the democratic political process implies that powerful interest groups have more influence than politically passive stakeholders do. Unlike corporate creditors, corporate managers have well-organized interest groups. Stock market participants have some influence, but they consider that their main arena is not corporate law, but securities regulation. $^{11}$

10. The reform plan was originally intended to mimic German corporate law, especially the codetermination system, but the reform plan was stalled immediately. The labour unions in Germany and those in Japan have different characteristics. The Japanese counterpart can easily influence corporate management through the lifetime employment system.

11. Japanese securities regulation is under the Financial Services Agency (FSA), not the MOJ, and the FSA has the Financial System Council (Kinyu Shingikai), instead of the Legislative Council. 
Now that the legislative process of corporate law reform has become more democratic, a process for striking a balance among various stakeholders is needed. One way is to increase the transparency of the legislative process, particularly with regard to the public-comment procedure.

\section{THE PUBLIC-COMMENT PROCEDURE AND CORPORATE LAW REFORM}

\subsection{The Public-Comment Procedure}

The political process in Japan had long been criticized as opaque because politicians and bureaucrats have made important policy decisions behind closed doors. Many people argued that the Japanese political process needed to be more transparent. It was also argued that politicians and bureaucrats needed to show the concrete content of their deliberations in policy formation, to hear public opinion, and to explain how final compromises are achieved. The transparency of the political process is an important feature of the democratic political process.

The Japanese government addressed these criticisms. On 23 March 1999, a cabinet decision was made to introduce the public-comment procedure-the Japanese version of the notice-and-comment procedure. The decision requires each branch of the government to publish a draft of regulations that it wants to introduce or reform and to invite comments on the draft. Although the branch is not forced to follow the collected comments from the public, it must publish a report that describes the distribution of the comments and how the branch has reacted, or not reacted, to the comments. In 2005, the public-comment procedure was formally incorporated into the reformed Administrative Procedure Act. ${ }^{12}$

The requirement of the public-comment procedure under the Administrative Procedure Act only applies to regulations and not to laws. This is because governmental branches do not have the power to make laws. It is the Diet that has the power to make laws. However, many governmental branches voluntarily employ the public-comment procedure when they draft legislative proposals of councils and Bills tabled in the Diet by the Cabinet. Corporate law is no exception, and the MOJ employs the public-comment procedure whenever it drafts a proposed corporate law reform. ${ }^{13}$

\subsection{Hypotheses}

Considering the political background of Japanese corporate law, several hypotheses emerge concerning the role of the public-comment procedure. The key in these hypotheses is that the public-comment procedure is implemented by the bureaucrats of the MOJ, and the effect of the procedure falls mainly on the bureaucrats. Therefore, observation of the behaviour of the bureaucrats around the procedure could reveal their internal motivations. The following are the five hypotheses on the effectiveness of the public-comment procedure:

1. The public-comment procedure has no effect (the no-effect hypothesis).

2. The public-comment procedure has a strong effect (the strong-effect hypothesis).

12. Harada (2011) studied the public-comment procedure in Japan more generally.

13. Note that MOJ had been collecting comments from various stakeholders during corporate law reforms well before the 2005 Administrative Procedure Act reform or the cabinet decision in 1999, such as in the 1974 Commercial Code Amendment. 
3. We can observe only the influence of powerful interest groups, namely the corporate managers (the interest-group hypothesis).

4. MOJ bureaucrats employ the public-comment procedure in order to countervail the pressure of interest groups (the independence hypothesis).

5. MOJ bureaucrats are legal specialists and are affected by only "convincing" comments (the persuasiveness hypothesis).

By applying an empirical analysis, this paper attempts to illuminate the hidden motives of the MOJ bureaucrats and to shed new light on the political environment of Japanese corporate law.

First, the no-effect hypothesis assumes that the MOJ bureaucrats engage in the publiccomment procedure in order to show that they abide by the Administrative Procedure Act and that their decision-making process is independent of the public-comment procedure. According to this hypothesis, we can predict that the solicited comments would not affect the final reform Bill drafted by the MOJ bureaucrats. ${ }^{14}$

Second, the strong-effect hypothesis assumes that the MOJ bureaucrats employ the publiccomment procedure as the Administrative Procedure Act expects. According to this hypothesis, the decision-making process of the MOJ bureaucrats is heavily influenced by the results of the public-comment procedure, thereby achieving a more democratic political process.

Third, the interest-group hypothesis assumes, similarly to the no-effect hypothesis, that the MOJ bureaucrats are not directly affected by the result of the public-comment procedure. It is assumed that the MOJ bureaucrats are willing to listen to the comments of powerful interest groups because resisting them is of no use under the new legislative process.

However, this prediction may not apply because the interest groups and the MOJ bureaucrats can behave strategically. The interest groups do not need to implement their desires through the public-comment procedure. They are able to do so during deliberation of the Legislative Council, before the public-comment procedure. In such cases, we cannot observe the direct influence of the interest group during the public-comment procedure.

Fourth, the independence hypothesis, which was proposed by Croley, ${ }^{15}$ assumes that bureaucrats are not simply under the pressure of interest groups, but that they try to fight against the interest groups by employing various procedures under the Administrative Procedure Act. In other words, the public-comment procedure is a means of counteracting the influence of politically powerful interest groups.

According to this hypothesis, we can predict that the comments solicited through the public-comment procedure can be employed strategically by the MOJ bureaucrats. Specifically, the comments of legal academics, who are considered politically neutral, are preferable to fighting against the pressure of corporate managers. Therefore, one prediction under this

14. Considering that the requirement of the public-comment procedure in case of the corporate law reform is not mandatory but voluntary, it is natural to expect that the MOJ bureaucrats utilize the public-comment procedure as an outlet for various interest groups.

15. Croley (2007) proposed a general theory on the relationship between executive branch and legislative branch in the US context. Although he did not mention corporate law reforms in Japan, it is interesting to see whether his general theory applies to the Japanese context. 
hypothesis is that the comments of legal academics and other groups have a significant effect on outcomes when corporate managers take conflicting positions.

Finally, the persuasiveness hypothesis focuses on the technical aspect of the publiccomment procedure. Although it is difficult to draw a clear prediction from this hypothesis, we can infer that technical comments, such as those of legal academics, courts, and bar associations, would influence the behaviour of the MOJ bureaucrats.

\section{DATA AND EMPIRICAL STRATEGY}

\subsection{Data}

\subsubsection{Constructing the Dataset}

As we have seen, the public-comment procedure could provide interesting material with which to investigate the behaviour of bureaucrats and the political environment of Japanese corporate law. However, unfortunately, the government releases only a report that summarizes and analyses the results of solicited comments but does not deliver the individual data of the solicited comments. Through these aggregated data, all we can know is the comments that are submitted and whether the original draft has been changed or not.

In contrast, in two reforms of Japanese corporate law, the 2002 reform and the 2005 reform, all the comments are published and available. ${ }^{16}$ These individual data provide us with an ideal source to test the aforementioned theoretical hypotheses. In addition, the 2002 reform and the 2005 reform have different characteristics: the 2002 reform was a fundamental and serious reform that introduced a US-like, committee-based corporate governance system, whereas the 2005 reform was minor and technical. However, the 2005 reform separated the Corporate Code from the Commercial Code, as the "modernization of corporate law," and thus was formally significant. This variation in data can also help us to identify various theoretical predictions.

In order to construct the dataset, we first divide the reform drafts into single issues. We then check the outcome to determine whether the final reform Bills that were submitted to the Diet were different from the original drafts or not. Regarding the explanatory variables, we count the number of affirmative and negative responses to each issue. We also classify the numbers according to who submitted each comment, such as business groups, financial institutions, academics, and others. The category of "others" includes courts, bar associations, non-profit organisations (NPOs), and so on.

We also employ the nature of issues as an explanatory variable. Some issues concern the tightening of regulations, so we expect that corporate managers will move against them. The two corporate law reforms were implemented when Junichiro Koizumi was the prime minister and deregulation was the political trend. The more regulatory a reform proposal, the more difficult it was to implement the reform. Others are enabling reforms, and we expect that corporate managers will support them, or at least will not object to them.

16. Civil Law Counselors Office (2001); Civil Law Counselors Office (2004). To be exact, not all comments are published. Only comments that the MOJ bureaucrats considered significant are published. Other frivolous comments are not published and unavailable. However, because we are interested in the behaviour and motivations of the MOJ bureaucrats and the political environment of Japanese corporate law, the disregard of such minor comments can be justified. 
Finally, we employ a proxy variable as an indicator of the predetermined attitude of the MOJ bureaucrats. When a draft applied to the public-comment procedure is already discussed thoroughly in the Legislative Council, the MOJ bureaucrats may not want to make significant changes to the original draft. We can infer such intentions of the MOJ bureaucrats by observing the language of the draft. When an issue uses the expression "shall be ... (monoto suru)," we can infer that the deliberation in the Legislative Council is already mature and that the MOJ bureaucrats are unwilling to modify the original draft. In contrast, when an issue uses expressions such as "How do you feel about the following alternatives?" or "Among the following three alternatives, which is the best?," we can infer that the deliberation in Legislative Council is not yet mature and that the MOJ bureaucrats are willing to accept suggestions from various groups.

\subsubsection{Summary Statistics}

Table 1 shows the summary statistics of the 2002 reform and Table 2 shows those of the 2005 reform.

The variable "Reform02" indicates whether the final reform Bill reflected the original draft or not. When the final Bill is the same as the original draft, the variable takes the value of one, and zero otherwise. Similarly, the variable "RegEn02" is the outcome variable, which takes the value of one when the final Bill is in enabling nature, minus one when the final Bill is in regulatory nature, and zero when the final Bill is neither enabling nor regulatory.

With respect to the independent variables, the variable "Yes (total)" is the total number of comments that supported the reform proposal, whereas the variable "No (total)" is the total number of comments that are against the reform proposal. The variables "Academics (Y)," "Business (Y)," "Fin. Inst. (Y)," and "Other (Y)" are the number of positive comments by academic institutions, business groups, financial institutions, and other groups, respectively. The variables "Academics (N)," "Business (N)," "Fin. Inst. (N)," and "Other (N)" are the number of negative comments for each category.

The variable "En (total)" is the total number of comments supporting reform alternatives that relax the existing regulations, whereas the variable "Reg (total)" is the total number of comments supporting reform alternatives that tighten the existing regulations. The variables “Academics (En)," "Business (En)," "Fin. Inst. (En)," and "Other (En)" are the number of comments that support enabling reform alternatives from academic institutions, business groups, financial institutions, and other groups, respectively. The variables "Academics (Reg)," "Business (Reg)," "Fin. Inst. (Reg)," and "Other (Reg)" are the number of comments that support regulatory alternatives for each category.

Finally, the variable "Regulatory" indicates whether the issue is regulatory (i.e. its value takes one) or enabling (i.e. its value takes zero). The variable "Expression" shows the attitude of the MOJ bureaucrats, and its value takes one when the reform draft uses the expression "shall be ...," and zero otherwise.

Comparison of the two datasets reveals several interesting remarks. First, the comparison of the success rate of the original proposal shows a large difference between the two reforms. The 2005 reform has a success rate of $81 \%$ ("Reform05"), whereas the 2002 reform has a success rate of only $64 \%$ ("Reform02"). This difference reflects the different characteristics of the two reforms. As described above, the 2002 reform was fundamental and drastic, 
Table 1. The 2002 reform

\begin{tabular}{lcccc}
\hline Variable & Mean & Standard deviation & Min. & Max. \\
\hline Reform02 & 0.642 & 0.484 & 0 & 1 \\
Yes (total) & 22.2 & 9.6 & 3 & 38 \\
No (total) & 11.2 & 10.5 & 0 & 42 \\
Academics (Y) & 8.72 & 4.52 & 0 & 18 \\
Business (Y) & 5.72 & 4.04 & 0 & 14 \\
Fin. Inst. (Y) & 0.925 & 1.11 & 0 & 4 \\
Other (Y) & 6.79 & 3.54 & 0 & 15 \\
Academics (N) & 4.94 & 4.82 & 0 & 20 \\
Business (N) & 3.09 & 5.38 & 0 & 18 \\
Fin. Inst. (N) & 0.774 & 1.6 & 0 & 6 \\
Other (N) & 2.34 & 2.41 & 0 & 8 \\
Regulatory & 0.264 & 0.445 & 0 & 1 \\
Expression & 0.83 & 0.379 & 0 & 1 \\
RegEn02 & 0.604 & 0.631 & $-1(\mathrm{REG})$ & $1(\mathrm{EN})$ \\
En (total) & 23.7 & 9.56 & 4 & 42 \\
Reg (total) & 9.62 & 8.54 & 0 & 36 \\
Academics (En) & 7.64 & 4.53 & 0 & 17 \\
Business (En) & 8.06 & 4.32 & 1 & 18 \\
Fin. Inst. (En) & 1.58 & 1.61 & 0 & 6 \\
Other (En) & 6.32 & 3.4 & 1 & 15 \\
Academics (Reg) & 6.15 & 5.47 & 0 & 20 \\
Business (Reg) & 0.755 & 1.71 & 0 & 8 \\
Fin. Inst. (Reg) & 0.113 & 0.32 & 0 & 1 \\
Other (Reg) & 2.87 & 3.29 & 0 & 12 \\
& & & & \\
\hline
\end{tabular}

whereas the 2005 reform was formal and technical. Therefore, it is not surprising that the 2002 reform proposal met with more objections than the 2005 reform proposal did.

Second, the ex-ante attitude of the MOJ bureaucrats also differs between the two reforms. In the 2002 reform, the MOJ bureaucrats had already decided their ex-ante position in $83 \%$ of the issues ("Expression"). In contrast, in the 2005 reform, the MOJ bureaucrats only showed an ex-ante fixed attitude in $68 \%$ of the issues ("Expression"). This difference could also be explained by the different characteristics of the two reforms. Because the 2002 reform was fundamental and the 2005 reform was technical, the issues involved in the 2005 reform were more subtle than those in the 2002 reform were. In order to seek "correct" answers in the 2005 reform, the MOJ bureaucrats needed to consider the balance among various technical details, although they were not politically important. It was, therefore, more difficult for the MOJ bureaucrats to locate their ex-ante decisions in the 2005 reform than in the 2002 reform.

Finally, the variable "Regulatory" also reveals the nature of the two reforms. In the 2002 reform, $26 \%$ of the issues concerns tightening existing regulations, but only $14 \%$ in the 2005 reform. Although the ratio of tightening proposals is not high, it implies how different in nature the two reforms are. Compared to the 2005 reform, the 2002 reform, which introduced the US-like committee-based corporate governance system, was more drastic and fundamental, and it contained many regulatory proposals. The subtler 2005 reform was technical. 
Table 2. The 2005 reform

\begin{tabular}{lcccr}
\hline Variable & Mean & Standard deviation & Min. & Max. \\
\hline Reform05 & 0.809 & 0.394 & 0 & 1 \\
Yes (total) & 16.3 & 6.54 & 1 & 31 \\
No (total) & 5.28 & 4.87 & 1 & 25 \\
Academics (Y) & 4.76 & 2.82 & 0 & 17 \\
Business (Y) & 3.8 & 2.29 & 0 & 11 \\
Fin. Inst. (Y) & 0.439 & 0.779 & 0 & 4 \\
Other (Y) & 7.39 & 3.08 & 0 & 19 \\
Academics (N) & 2.89 & 3.05 & 0 & 17 \\
Business (N) & 0.554 & 1.06 & 0 & 4 \\
Fin. Inst. (N) & 0.197 & 0.512 & 0 & 3 \\
Other (N) & 1.64 & 2.32 & 0 & 11 \\
Regulatory & 0.14 & 0.348 & 0 & 1 \\
Expression & 0.675 & 0.47 & 0 & 1 \\
RegEn05 & 0.407 & 0.767 & $-1(\mathrm{REG})$ & $1(\mathrm{EN})$ \\
En (total) & 14 & 7.69 & 1 & 28 \\
Reg (total) & 8.49 & 6.98 & 0 & 31 \\
Academics (En) & 3.41 & 2.73 & 0 & 13 \\
Business (En) & 4.26 & 2.18 & 0 & 10 \\
Fin. Inst. (En) & 0.457 & 0.762 & 0 & 4 \\
Other (En) & 5.97 & 3.84 & 0 & 19 \\
Academics (Reg) & 4.51 & 3.69 & 0 & 17 \\
Business (Reg) & 0.507 & 0.909 & 0 & 4 \\
Fin. Inst. (Reg) & 0.207 & 0.53 & 0 & 3 \\
Other (Reg) & 3.26 & 3.28 & 0 & 13 \\
\hline
\end{tabular}

\subsection{Empirical Strategy}

\subsubsection{Empirical Model}

We employ a standard probit regression in order to analyze the effect of solicited comments on the reform of corporate law. Under the normal latent utility models, the MOJ bureaucrats adopt the original draft when their latent utility goes above a threshold and reject the original draft when the latent utility falls below the threshold:

$$
\begin{aligned}
& \text { Reform }^{*}=\mathbf{x} \beta+\mathbf{z} \gamma+\epsilon \\
& \text { Reform }=1\left[\text { Reform }^{*}>0\right],
\end{aligned}
$$

where Reform* is a latent utility of the MOJ bureaucrats, Reform is an observed variable that takes one when the original draft is adopted and zero otherwise; $\mathbf{x}$ is a vector of the solicited comments; $\mathbf{z}$ is a vector of other explanatory variables; $\beta$ and $\gamma$ are coefficients of each vector to be estimated; and $\varepsilon$ is the unobservable term.

Under this standard model, we can estimate the parameter coefficients via the probit regression. However, some issues are not simple dichotomies of success or failure. When the original draft presents multiple alternatives, some alternatives are more regulatory, and others are more enabling. In such a case, we cannot employ simple probit regression, because the dependent variable is not a binomial variable. We then need to employ 
an ordered probit regression, because the dependent variable can be seen as an ordered categorical variable. $^{17}$

An implicit and important assumption of this specification is that the number of supporting or objecting comments is an appropriate proxy for the importance of the submitter's view. Although we know that the number of comments does not necessarily correlate with the underlying distribution and power of the submitter's view, there are several reasons for employing this proxy variable.

First, even if we cannot establish a direct causal relationship between the two factors, it is plausible to consider that some level of correlation exists between them. When the number of comments is large, the likelihood of persuasive comments will be higher. Second, submitting comments incurs costs on the part of their submitter. In order to justify such costs, s/he has considerable incentive to make the comments as powerful as possible. Finally, it is difficult to measure the quality of the solicited comments, other than their number.

\subsubsection{Predictions from the Hypotheses}

Before discussing the result of analysis, we construct predictions according to the five theoretical hypotheses discussed in Section 3.2.

First, under the no-effect hypothesis, no comments will have a significant effect. In contrast, the "Expression" variable, which indicates whether the issue is already fixed at the deliberation stage in the Legislative Council, will have a significant positive effect. When a thorough deliberation has already been done, the original draft will be adopted without significant modifications during the public-comment procedure.

Second, under the strong-effect hypothesis, the numbers of affirmative and negative responses will have a significant effect on the outcome. In contrast, the "Expression" variable will have no significant effect, because the MOJ bureaucrats have second thoughts on the original draft.

Third, under the hypothesis of interest-group pressure, only the numbers of affirmative and negative responses by business groups will have a significant effect on the result. In contrast, other comments do not have strong political background and will not have a significant effect.

Fourth, under the independence hypothesis, the numbers of affirmative and negative responses of the business groups are not significant, or even negatively significant. Because the MOJ bureaucrats try to counteract the powerful interest groups, they will rely on the comments of other groups. Hence, the other comments will have a significant positive effect.

Finally, under the persuasiveness hypothesis, the comments of some professionals, such as legal academics, courts, and bar associations, will have a significant effect on the outcome. On the other hand, the comments of business groups may not have a significant effect, because these groups tend to provide biased discussion although they are a well-organized political interest group.

17. Another possibility is that the dependent variable is not ordered among the categories and thus is not an ordered categorical variable, but a multinomial variable. For robustness, we also tried a multinomial-probit regression and found that the fundamental results were the same as those from ordered probit regression. Therefore, we report only the results of the ordered probit regression in this paper. 


\section{RESULTS}

\subsection{The 2002 Reform}

In this subsection, we discuss the results from the 2002 reform dataset. Table 3 presents the results of the probit models where the dependent variable is whether the final reform Bill, the outcome, was the same as the original draft was before the public-comment procedure (i.e. success), or different (i.e. failure).

These results indicate several interesting points about the testable hypotheses mentioned above. Column (1) shows that the numbers of affirmative and negative responses are both statistically significant and that their signs are correct. In contrast, the variable "Expression" is not significant, although it has a positive sign. This result supports the strong-effect hypothesis but is not consistent with the no-effect hypothesis. The MOJ bureaucrats were influenced by the outcome of the public-comment procedure, because they implemented their original proposal when many comments were supportive, and they modified it when many comments were unsupportive. Whether they had already made up their minds was not crucial.

This is probably because the 2002 reform differs in nature from the 2005 reform. As discussed above, the 2002 reform was a fundamental reform, whereas the 2005 reform was technical. Therefore, the 2002 reform had a greater impact on many corporate stakeholders than the 2005 reform did, and the claims of such stakeholders could have more serious political influence on the legislative process. The MOJ bureaucrats were not able to ignore the corporate stakeholders, so they considered the outcome of the public-comment procedure more seriously.

However, when we decompose the influence of various groups as shown in column (2) of Table 3, this correlation disappears. One reason for this phenomenon is that the 2002 reform contained a relatively small number of issues (53) and that the increased number of explanatory variables (and the decreased degree of freedom) reduced the statistical significance. According to this result, we cannot deduce any implication with respect to the hypotheses noted above.

In order to understand the individual influence of various groups, we further performed an ordered probit regression as shown in Table 4. As the table shows, the dependent variable is an ordered variable, which takes minus one when the final Bill was to tighten existing regulations and positive one when the final draft was to relax existing regulations, and zero otherwise. Therefore, we can say that explanatory variables whose coefficients have positive values push the original reform proposal toward relaxing existing regulations, whereas explanatory variables with negative coefficients push it toward tightening existing regulations.

The results of the standard model are reported in column (3) of Table 4. Although the enabling comments of academics have the wrong sign, they are barely (10\%) significant. Other statistically significant coefficients have interesting implications. First, the enabling comments from "Others" are positive and significant. This implies that the comments of courts, bar associations, and NPOs could be influential. When these groups supported an enabling alternative, the MOJ bureaucrats regarded the support as a green light for the reform.

Second, the regulatory comments of legal academics are negative and significant. When legal academics strongly pushed a regulatory alternative, the MOJ bureaucrats tried to implement that alternative. This result can be regarded as evidence supporting both the independence hypothesis and the persuasiveness hypothesis. However, if the corporate 
Table 3. The 2002 reform: probit models

(1)

(2)

\begin{tabular}{lr}
\hline Yes (total) & $0.0583^{*}$ \\
& $(0.0293)$ \\
No (total) & $-0.0483^{*}$ \\
& $(0.0216)$
\end{tabular}

Academics (Y)

0.0985

Business (Y)

$(0.115)$

Busins $(Y)$

0.0319

Fin. Inst. (Y)

(0.0970)

Others (Y)

0.240

$(0.397)$

Academics (N)

$-0.0213$

(0.124)

Business (N)

$-0.0996$

(0.0880)

Fin. Inst. (N)

0.0806

(0.126)

Others (N)

$-0.738$

(0.602)

Expression

1.19

$-0.268$

(0.196)

$N$

Log-likelihood

$-20.48$

$-16.09$

NOTES: Standard errors are in parentheses. $*$ denotes $5 \%$ level significance.

managers could exercise their influence outside the public-comment procedure, this result cannot rebut the interest-group hypothesis.

We next discuss the significance of the interaction term between "Expression" and "Regulation." Because column (3) in Table 4 introduces both "Expression" and the interaction term, the interaction term implies the effect of the MOJ bureaucrats' fixed attitude toward issues that tighten existing regulations, whereas "Expression" implies the effect about issues that relax existing regulations.

As noted above, the corporate law reform was an attempt to revive the Japanese economy from an economic downturn, and relaxing regulations was the main agenda item during the Koizumi cabinet. Under such circumstances, a reform proposal that tightened existing regulations must have gone through discussion already in the Legislative Council, and it was difficult to modify the original proposal after observing the outcome of the public-comment procedure.

However, when we confine the sample to the issues of whether the MOJ bureaucrats' attitude was already fixed (column (4)), the influence of various groups disappears and some coefficients are barely significant ( $10 \%$ level). These smaller effects can be explained by the fixed attitude of the MOJ bureaucrats. ${ }^{18}$

18. Of course, the number of observations in column (4) is only 44 , and the small size of this sample is unquestionably another reason for the smaller effects. 
Table 4. The 2002 reform: ordered probit models

\begin{tabular}{lcc}
\hline & All issues & Issues with "shall be" \\
& $(\mathbf{3})$ & $\mathbf{( 4 )}$ \\
\hline Academics (En) & $-0.261^{\dagger}$ & -0.133 \\
& $(0.134)$ & $(0.136)$ \\
Business (En) & -0.0336 & -0.0704 \\
& $(0.0731)$ & $(0.0933)$ \\
Fin. Inst. (En) & 0.299 & -0.170 \\
& $(0.238)$ & $(0.285)$ \\
Others (En) & $0.634^{*}$ & $0.391 \dagger$ \\
& $(0.262)$ & $(0.217)$ \\
Academics (Reg) & $-0.183^{*}$ & -0.0223 \\
& $(0.0923)$ & $(0.0902)$ \\
Business (Reg) & 0.177 & 0.113 \\
& $(0.160)$ & $(0.196)$ \\
Fin. Inst. (Reg) & -0.0467 & $2.30^{\dagger}$ \\
& $(0.699)$ & $(1.29)$ \\
Others (Reg) & 0.159 & $-0.306^{\dagger}$ \\
Expression & $(0.168)$ & $(0.168)$ \\
& 1.50 & \\
Exp $\times$ Regulation & $(0.916)$ & \\
$N$ & $-2.65^{* *}$ & 44 \\
Log-likelihood & $(0.930)$ & -16.48 \\
\hline
\end{tabular}

NOTES: Standard errors are in parentheses. ${ }^{\dagger}, *$, and $* *$ denote $10 \%, 5 \%$, and $1 \%$ level significance, respectively.

\subsection{The 2005 Reform}

As discussed above, the 2002 reform dataset is not powerful because of the small number of observations. In contrast, the 2005 reform dataset provided a richer environment for statistical analysis. The probit models have 157 observations, and the ordered probit models have 140 observations. The results of the analyses are shown in Tables 5 and 6.

First, column (1) in Table 5 presents the results of the simplest specification. As in the 2002 reform dataset, the numbers of affirmative and negative responses are statistically significant, and their signs are correct. However, in the 2005 reform dataset, the variable "Expression" is both statistically and economically significant, which implies that the MOJ bureaucrats tended to stick to their original proposal once they had made up their minds. The same relationship is shown in column (2). This finding supports the independence hypothesis.

Let us consider the reason for the difference between the two corporate law reforms. As noted above, the 2002 reform and the 2005 reform have different characteristics. The 2002 reform was fundamental, and the 2005 reform was formal and technical. This difference can provide an explanation for the results, as follows. The 2002 reform involved many high-stakes issues, and it was difficult for the MOJ bureaucrats to carry through their original proposal against opposition from the corporate stakeholders. The 2005 reform was technical and subtle, which made it relatively easy for the MOJ bureaucrats to stick to their original proposal. 
Table 5. The 2005 reform: probit models

\begin{tabular}{|c|c|c|c|}
\hline & \multicolumn{2}{|c|}{ All issues } & \multirow{2}{*}{$\begin{array}{l}\text { Issues with "shall be" } \\
\text { (3) }\end{array}$} \\
\hline & (1) & (2) & \\
\hline Yes (total) & $\begin{array}{l}0.0728 * * \\
(0.0258)\end{array}$ & & \\
\hline No (total) & $\begin{array}{c}-0.101 * * \\
(0.0287)\end{array}$ & & \\
\hline Academics (Y) & & $\begin{array}{c}0.0362 \\
(0.0812)\end{array}$ & $\begin{array}{c}0.244 \\
(0.174)\end{array}$ \\
\hline Business (Y) & & $\begin{array}{l}0.468 * * \\
(0.159)\end{array}$ & $\begin{array}{r}0.535 \dagger \\
(0.303)\end{array}$ \\
\hline Fin. Inst. (Y) & & $\begin{array}{c}0.398 \\
(0.340)\end{array}$ & $\begin{array}{c}-0.156 \\
(0.480)\end{array}$ \\
\hline Others (Y) & & $\begin{array}{c}-0.0395 \\
(0.0997)\end{array}$ & $\begin{array}{c}0.0419 \\
(0.198)\end{array}$ \\
\hline Academics $(\mathrm{N})$ & & $\begin{array}{c}-0.254 * * \\
(0.0917)\end{array}$ & $\begin{array}{c}-0.339^{\dagger} \\
(0.187)\end{array}$ \\
\hline Business (N) & & $\begin{array}{c}0.125 \\
(0.160)\end{array}$ & $\begin{array}{r}0.0181 \\
(0.381)\end{array}$ \\
\hline Fin. Inst. (N) & & $\begin{array}{c}0.0494 \\
(0.324)\end{array}$ & $\begin{array}{c}0.121 \\
(0.615)\end{array}$ \\
\hline Others $(\mathrm{N})$ & & $\begin{array}{c}-0.222^{*} \\
(0.102)\end{array}$ & $\begin{array}{c}-0.134 \\
(0.224)\end{array}$ \\
\hline Expression & $\begin{array}{l}0.933 * * \\
(0.331)\end{array}$ & $\begin{array}{l}1.14 * * \\
(0.384)\end{array}$ & \\
\hline$N$ & 157 & 157 & 106 \\
\hline Log-likelihood & -46.09 & -40.15 & -15.20 \\
\hline
\end{tabular}

Second, column (2) shows which groups had more influence through the public-comment procedure. As shown in column (2), the supporting comments of business groups had a positive influence on the outcome. If a technical reform proposal garnered support from corporate managers, it was a green light for the proposal. This can be interpreted as weak support for the interest-group hypothesis. Such technical issues might not receive much attention from corporate managers during the discussion in the Legislative Council, and corporate managers would consider the public-comment procedure as another venue for implementing their goals.

In contrast, the negative comments of legal academics and other institutions, such as courts and law firms, had a negative and significant effect on the outcome, as shown in column (2). One interpretation of this result is that the MOJ bureaucrats considered objections from professionals seriously because the latter could sometimes provide deeper insight into technical issues and point out critical shortcomings. Hence, this result provides evidence to support the persuasiveness hypothesis.

It is tempting to interpret the result as providing moderate support for the independence hypothesis, because the MOJ bureaucrats employed the objections from legal academics and other institutions in order to modify the original reform proposal. However, if the 
Table 6. The 2005 reform: ordered probit models

\begin{tabular}{lcc}
\hline & All issues & Issues with “shall be" \\
& $(\mathbf{4})$ & $\mathbf{( 5 )}$ \\
\hline Academics (En) & 0.0618 & -0.475 \\
& $(0.0781)$ & $(0.295)$ \\
Business (En) & $0.200^{*}$ & $0.576^{\dagger}$ \\
& $(0.0947)$ & $(0.323)$ \\
Fin. Inst. (En) & 0.227 & -0.196 \\
& $(0.234)$ & $(0.480)$ \\
Others (En) & 0.0433 & 0.256 \\
& $(0.0742)$ & $(0.278)$ \\
Academics (Reg) & $-0.0822^{\dagger}$ & -0.349 \\
& $(0.0494)$ & $(0.220)$ \\
Business (Reg) & -0.0707 & -0.291 \\
& $(0.172)$ & $(0.787)$ \\
Fin. Inst. (Reg) & -0.107 & 0.297 \\
& $(0.235)$ & $(0.681)$ \\
Others (Reg) & -0.0492 & -0.0765 \\
& $(0.0768)$ & $(0.289)$ \\
Expression & $1.64 * *$ & \\
Exp $\times$ Regulation & $(0.366)$ & 77 \\
$N$ & -6.88 & -11.88 \\
Log-likelihood & $(284)$ & \\
& 140 & \\
\hline
\end{tabular}

NOTES: Standard errors are in parentheses. ${ }^{\dagger}, *$, and $* *$ denote $10 \%, 5 \%$, and $1 \%$ level significance, respectively.

independence hypothesis holds true, both the positive and negative comments of legal academics and other institutions must have a significant effect. The insignificance of the positive comments of legal academics and other institutions implies that the support from the legal academics and other institutions does not have the power to overcome the influence of powerful interest groups, namely the corporate managers.

The results shown in column (3) confirm the results shown in columns (1) and (2). In columns (1) and (2), the "Expression" variable has a statistically and economically significant positive effect on the outcome. Therefore, we can predict that, if we focus on issues in which the attitudes of the MOJ bureaucrats were already fixed, few groups could have affected the outcome. As expected, we found that almost all explanatory variables were either not significant or only barely significant.

Next, we turn to the results of the ordered probit models (Table 6). The results shown in column (4) in Table 6 confirm those in column (2) in Table 5. When business groups submitted many comments that supported the enabling proposal, such comments had a positive effect on the outcome. When legal academics submitted many comments that supported the regulatory proposal, such comments also had a positive effect on the outcome. The explanation of these results is similar to that for those shown in column (2).

Regarding the ex-ante attitude of the MOJ bureaucrats, only the proposals that relax the existing regulations have a positive effect on the outcome, whereas the proposals that tighten 
the existing regulations do not. This is probably because only a few observations were made of the latter case, which explains its explosive standard error (284). Therefore, we do not consider the difference between the variable "Expression" and the interaction term seriously. The ex-ante attitude of the MOJ bureaucrats had a significant effect on the outcome, as also shown in columns (1) and (2) in Table 5.

In addition, the results shown in column (5) confirm those in column (3) in Table 5. When we focus on issues about which the attitudes of the MOJ bureaucrats were fixed ex ante, the influence of almost all groups becomes insignificant. This result supports the no-effect hypothesis.

\section{CONCLUDING REMARKS}

This paper constructs two innovative hand-collected datasets and analyses them in order to understand another aspect of the political environment of corporate law reforms in Japan. Although no hypothesis universally holds true, and each hypothesis is applicable to limited situations, we reached several important conclusions.

First, the MOJ bureaucrats have considerable control over the public-comment procedure. This control was strongly evident in the 2005 reform proposal, which was formal and technical, not substantial. This result partly supports the no-effect hypothesis, under which the MOJ bureaucrats engage only superficially in the public-comment procedure. They are not willing to hear the voices of the public when the issue is technical and in their own arena.

Second, although corporate managers have critical influence on the reform process of corporate law, during the public-comment procedure, their influence is limited to a few cases. When an issue is technical and not fully discussed in the Legislative Council, corporate managers employ the public-comment procedure as another venue for achieving their interests. Thus, the interest-group hypothesis is not strongly supported in the case of the public-comment procedure.

Finally, legal academics and other legal professional institutions, such as courts, bar associations, and law firms, have influence in some cases. This result provides supporting evidence for the persuasiveness hypothesis, under which technical comments can persuade the MOJ bureaucrats to make a "better" corporate law. However, we cannot find supporting evidence for the independence hypothesis, under which the MOJ bureaucrats employ the public-comment procedure in order to counteract the influence of politically powerful interest groups.

This paper highlights the importance of the behaviour and the roles of bureaucrats of MOJ in the Japanese law-making process. The bureaucrats of MOJ shape the law-making process in a fundamental way. At the same time, the paper also highlights the limit of the role of the bureaucrats. When the stake is considerable, strong interest groups can restrain the behaviour of the bureaucrats. However, when the ruling party only cares about the stock price (Nikkei 225 average) in order to maintain public support and does not listen to the voice of the strong interest groups (corporate managers), the bureaucrats can recapture their discretion. We can observe realizations of this scenario under the second Abe government (2012- ): the 2014 reform of corporate law, the introduction of Stewardship Code, and the introduction of Corporate Governance Code. 
This paper utilizes data from only two public-comment procedures. Japanese corporate law is now undergoing another reform process. The political environment surrounding this process has already changed from that surrounding the 2005 reform. Further research would be desirable in order to understand the changing political environment of Japanese corporate law.

\section{REFERENCES}

Caplan, Bryan (2007) The Myth of the Rational Voter: Why Democracies Choose Bad Policies, Princeton: Princeton University Press.

Civil Law Counselors Office, Ministry of Justice (2001) Kaisha Hosei no O'habana Minaoshi ni kansuru Kakkai Iken no Bunseki: Kaishaho no Bappon Kaisei ni kakaru 'Chukan Shian' ni taisuru Iken [Analysis of Comments to 2002 Corporate Law Reform Draft], Tokyo: Shojihomu Kenkyukai. (in Japanese).

Civil Law Counselors Office, Ministry of Justice (2004) Kaisha Hosei no Gendaika ni kansuru Yoko Shian ni taisuru Kakkai Iken no Bunseki [Analysis of Comments to 2005 Corporate Law Reform Draft], Tokyo: Shojihomu Kenkyukai (in Japanese).

Croley, Steven P. (2007) Regulation and Public Interests: The Possibility of Good Regulatory Government, Princeton: Princeton University Press.

Harada, Hisashi (2011) Ko'han'i Otogata no Kanryosei: Paburikku Komento Tetsuduki no Kenkyu [Bureaucracy System Responding to Various Stakeholders: A Research on Public Comment Procedure], Tokyo: Shinzansha (in Japanese).

Kato, Junko (1994) The Problem of Bureaucratic Rationality: Tax Politics in Japan, Princeton: Princeton University Press.

Milhaupt, Curtis J. (2003) "A Lost Decade for Japanese Corporate Governance Reform? What's Changed, What Hasn't, and Why," https://ssrn.com/abstract=442960 (accessed 4 April 2017).

Morita, Hatsuru (2005) "Paburikku Komento Tetsuzuki ha Yuko ni Kino Shiteiruka? Shoho Kaisei wo Meguru Pabulikku Komento Tetuduki no Jisshobunseki ["Is Public Comment Procedure Effective? An Empirical Analysis of Public Comment Procedure around Corporate Law Reforms"]." 133 Mishoho Zasshi 237-68 (in Japanese).

Morita, Hatsuru (2014a) Jisshou Bunseki Nyumon [Introduction to Empirical Legal Analysis], Tokyo: Nippon Hyoronsha (in Japanese).

Morita, Hatsuru (2014b) "Reforms of Japanese Corporate Law and Political Environment." 37 Zeitschrift für Japanisches Recht 25-38.

Roe, Mark J. (1996) Strong Managers, Weak Owners: The Political Roots of American Corporate Finance, Princeton: Princeton University Press.

West, Mark D. (2001) "The Puzzling Divergence of Corporate Law: Evidence and Explanations from Japan and the United States." 150 University of Pennsylvania Law Review 527-601. 